\title{
De novo design of small molecule inhibitors targeting the LEDGF/p75-HIV integrase interaction $\uparrow$
}

\author{
Claudia Cavalluzzo, $\dagger^{a}$ Arnout Voet, $\dagger^{b}$ Frauke Christ, ${ }^{c}$ Brajendra Kumar Singh, ${ }^{a d}$ Ajendra Sharma, ${ }^{a}$ Zeger \\ Debyser, ${ }^{c}$ Marc De Maeyer ${ }^{b}$ and Erik Van der Eycken*a
}

Received 11th August 2011, Accepted 18th October 2011

DOI: $10.1039 / \mathrm{c} 1 \mathrm{ra00582k}$

The integration of the viral DNA into the host genome is one of the essential steps in the HIV replication cycle. This multistep process mediated by the viral enzyme integrase (IN) allows identification and development of inhibitors targeting different integrase activities. Lens epitheliumderived growth factor (LEDGF/p75) has recently been identified as a crucial cellular co-factor of integration that acts by tethering IN to the cellular chromatin. Small molecules inhibiting the LEDGF/p75-IN interaction may become new and highly active antiretroviral therapeutic agents. In this paper we report the rational design, synthesis and evaluation of inhibitors that target the LEDGF/p75 protein and compete with IN binding. These molecules are designed to mimic the integrase alpha-3 helix, which interacts with LEDGF/p75, using pharmacophore guided scaffold replacement. The inhibitor 3-(1H-indol-3-ylthio)- $N$-(2-isopropoxy-6-methoxypyridin-3-yl)benzamide (CAB1) and its derivatives (CAB2-13) inhibit the LEDGF/p75-IN protein-protein interaction with moderate potency. These $\mathbf{C A B}$ inhibitors are the first reported example of small molecules targeting the LEDGF/p75 partner of the protein-protein interaction, in contrast to the previously reported compounds which target the integrase partner.

\section{Introduction}

Since the discovery of HIV as the causative agent of AIDS more than 25 years ago, virus spreading in pandemic proportions resulted in the death of more than 25 million people. ${ }^{1}$ More than 20 drugs have been approved for the treatment of HIV infection, significantly improving patients' life expectancy. Most drugs target the viral proteins such as Reverse Transcriptase, Protease or Integrase. Enfuvirtide and Maraviroc on the other side inhibit the entry of the viral particle into the host cell. ${ }^{2}$ Unfortunately all drugs approved for use in patients have given rise to resistance occurrence. Hence there is a necessity for the development of new antiretroviral agents with high potency against a wider range of viral variants and potentially a higher barrier towards resistance development. ${ }^{3}$ The viral integrase enzyme (IN), with its multiple functions in the early HIV replication cycle, is an appealing target for the development of new antiretrovirals. Currently only the

${ }^{a}$ Laboratory for Organic Katholieke Universiteit Leuven, Celestijnenlaan 200F, B-3001, Leuven, Belgium.

E-mail: erik.vandereycken@chem.kuleuven.be; Fax: +3216327990

${ }^{b}$ Laboratory for Biomolecular modeling; Katholieke Universiteit Leuven, Celestijnenlaan 200G, B-3001, Leuven, Belgium

${ }^{c}$ Molecular Medicine, Katholieke Universiteit Leuven, Kapucijnenvoer 33, B-3000, Leuven, Flanders, Belgium

${ }^{d}$ Present address: Bioorganic Laboratory, Department of Chemistry,

University of Delhi, Delhi, 110 007, India

$\dagger$ Electronic supplementary information (ESI) available. See DOI: $10.1039 / \mathrm{c} 1 \mathrm{ra} 00582 \mathrm{k}$

$\$$ the authors equally contributed to the paper. strand transfer inhibitor Raltegravir has been approved for clinical use, but resistance mutations rapidly occur. ${ }^{4}$

IN is a $32 \mathrm{kDa}$ protein responsible for the integration of the viral cDNA into the host genome. ${ }^{5}$ It is subdivided into three structural domains: the N-terminal domain (NTD), the catalytic core domain (CCD) and the C-terminal domain (CTD) and forms multimeric complexes. ${ }^{6-9}$ IN mediates two enzymatic reactions: (i) the cleavage of a dinucleotide from the $3^{\prime}$ ends of linear viral cDNA, and (ii) the transesterification of the processed cDNA into the human chromatin. ${ }^{5}$

The multistep integration process is an interesting target for the development of various inhibitor classes due to its complexity and the multimeric quaternary structure including the interaction with a human protein, LEDGF/p75. ${ }^{10}$ This cofactor was identified as a tight binding partner of HIV IN and found to be crucial for the insertion of the viral cDNA into the host genome. ${ }^{11-13}$ The LEDGF/p75-IN interaction is mediated by the CCD of IN that binds to the IN binding domain (IBD) present in the C-terminal region of LEDGF/p75. Through this interaction LEDGF/p75 functions as a tethering factor linking the integration complex to the chromatin. ${ }^{10,11,14}$ Of major importance for the validation of $\mathrm{LEDGF} / \mathrm{p} 75$ as a target for antiretroviral therapy was the demonstration that the overexpression of the IBD of LEDGF/p75 can efficiently compete with endogenous LEDGF/p75 and potently inhibits HIV replication. ${ }^{15,16}$

Targeting the LEDGF/p75-IN interaction with Small Molecule Protein-Protein Interaction Inhibitors (SMPPIIs) is a 
new strategy for the development of antiretroviral therapeutics. Up to now, only a few inhibitors of the HIV-1 IN-LEDGF/p75 complex have been reported, all binding to the IN component of the protein-protein interactions. ${ }^{17}$ The first reported molecule, D77, was identified during a screening approach and is reported to inhibit the LEDGF/p75-IN interaction in vitro. ${ }^{18}$ Next, CHIBA3003, an IN strand transfer inhibitor derivative displaying micromolar inhibition of the LEDGF/p75-IN interaction, was reported. ${ }^{19}$ Both compounds bind to the dimer interface of IN but did not display antiviral activity in cell culture. Recently LEDGINs were reported as the first class of LEDGF/p75-IN inhibitors, with potent antiviral activity in cell culture. ${ }^{20}$ These compounds were derived from molecules identified by a virtual screening strategy. The LEDGINs target the CCD interfere with its interaction with LEDGF/p75-IBD. They provide proof-of-principle that rational design is a valid approach to develop protein-protein interaction inhibitors with antiviral activity. Crystal structures of the compounds soaked in the CCD dimer confirmed their binding mode and mechanism of action on a structural level. Resistance selection resulted in the integrase Ala-128-Thr mutation, indicating that LEDGINs indeed bind in the integrase pocket as required during the computational drug discovery setup. This occurrence of resistance however opened the search for molecules targeting the LEDGF/p75-IN interaction with a potentially higher genetic barrier to resistance. It is generally believed that binding to the human protein (LEDGF/p75) and not the viral protein (IN) will make resistance selection difficult for the virus. ${ }^{20}$ Nevertheless, this approach may induce increased toxicity since the human proteins can interact with other cellular binding partners. In fact, LEDGF/ p75 interacts with several human proteins such as JPO2, ${ }^{21} \operatorname{PogZ}{ }^{22}$, the S-phase kinase ${ }^{23}$ and Menin. ${ }^{24}$

Here we report the rational design, synthesis and evaluation of small molecules binding to LEDGF/p75 and inhibiting the LEDGF/p75-IN interaction in vitro. These molecules are the first example of SMPPIIs targeting LEDGF/p75 and not IN, thus giving the possibility of developing new antiretrovirals without rising resistance. Molecular modeling allowed us to design a compound (referred to as CAB1), that mimics the alpha3 helix of IN, a major contributor of the IBD-CCD interaction.
The inhibitory activities of the small molecules were determined using a proximity based luminescence method.

\section{Results and discussion}

\section{Design of the molecules}

The CAB inhibitors were designed to mimic the interaction of the crucial amino acids (Thr-124, Ala-127 and Trp-131) of the integrase alpha-3 helix (Fig. 1) with LEDGF/p75 without resembling a classical alpha helix mimetic.

This rational approach was preferred over other classical methodologies, which also employ the structural information as available in the crystal structure of the protein complex, such as the discovery through virtual screening of small molecule ligands (employing pharmacophore modeling or molecular docking) or the design and synthesis of an alpha helix mimetic. ${ }^{25}$ In fact, a virtual screening experiment, similar to the approach previously used to discover IN-binding molecules for this interaction, ${ }^{20}$ was performed. Molecules that passed the pharmacophore query (based on the protein interaction interface) were subsequently docked to the LEDGF/p75 interface; however none of these docked molecules fulfilled the prerequisite binding mode according to the pharmacophore model, and their predicted affinity was much lower than classically observed in docking simulations. As such this approach was abandoned.

A second attempt focused on the design of an alpha helix mimetic incorporating the key interacting groups (Thr-124, Ala-127 and Trp-131, see Fig. 2A) such that the functionalities grafted on a scaffold overlap with the geometry of the interacting amino acids in a relaxed conformation (see Fig. 2B and C). This option was modelled, but the interaction of a functionalized alpha helix mimetic scaffold in complex with the IBD structure indicated that over $70 \%$ of the compounds' solvent accessible surface area was solvent exposed (see Fig. 2D). Furthermore, during docking simulations such compounds bound in a completely different conformation than intended. As the required binding mode is rather unlikely to exist, we opted for another de novo design strategy.

This strategy combines the knowledge gained from the two previously explored methods. The pharmacophore model, used
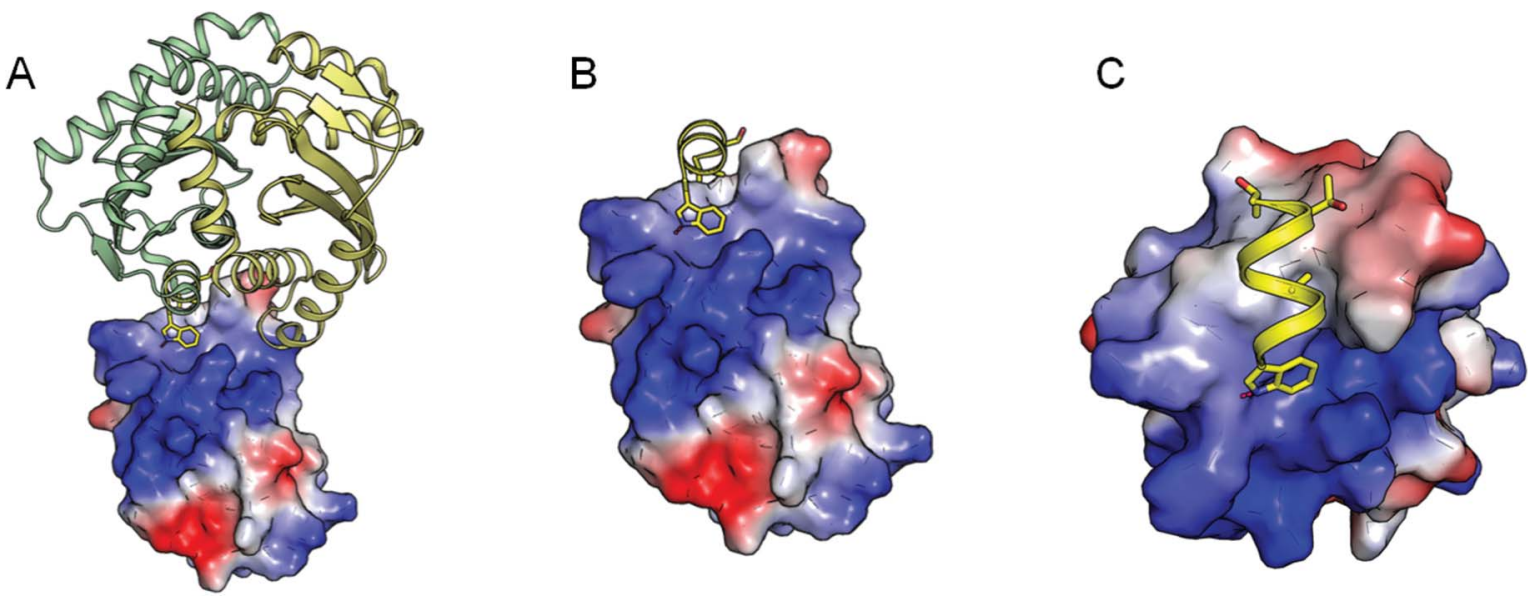

Fig. 1 Schematic representation of the IBD structure (electrostatics are mapped on the molecular surface) in complex with the integrase CCD dimer (green-yellow cartoon A). The key interacting amino acid Trp-131 (sticks) of the alpha 3 helix (yellow cartoon) is depicted in panel B and C in different orientations to highlight the interaction of the residue in a subducted surface of the IBD. 
A

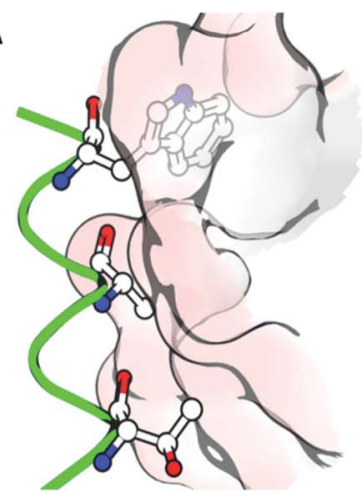

B

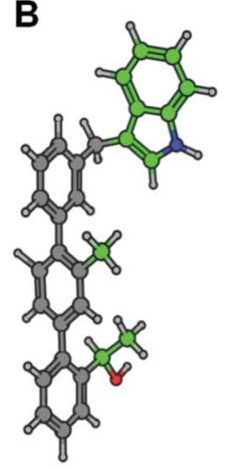

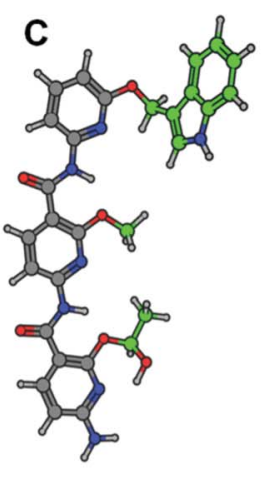
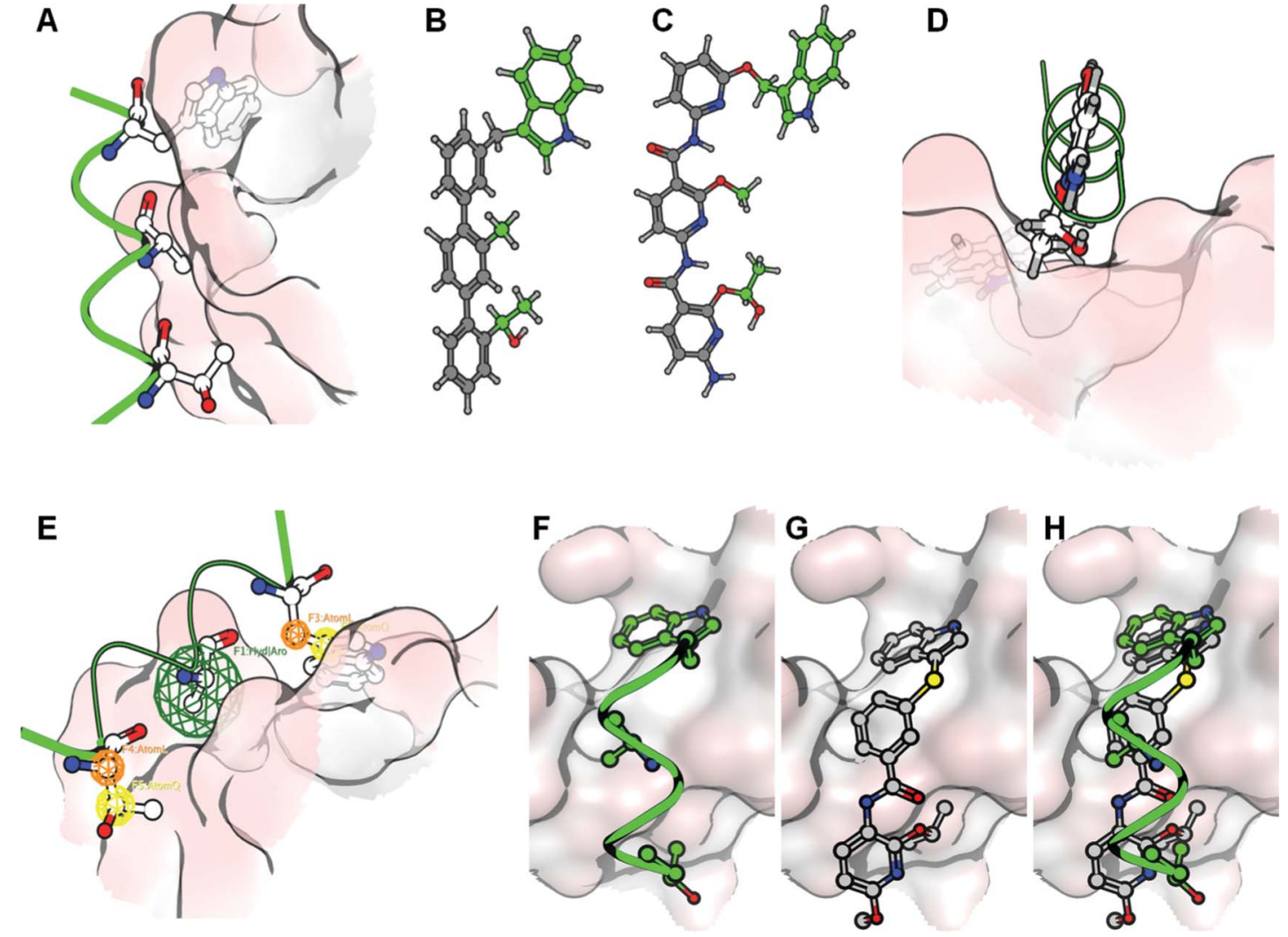

Fig. 2 From the alpha-3 helix mimic to the de novo design strategy: the interaction of the alpha- 3 helix with the IBD is mainly exerted by 3 amino acids (Thr-124, Ala- 127 and Trp-131) (A). These can be transferred onto helix-mimetic scaffolds such as the molecules depicted in B and C. These molecules however are unlikely to bind to the IBD surface since the major part of the molecule is solvent exposed (D). Therefore a scaffold incorporating the key amino acid interactions using pharmacophore features was used to design an inhibitory molecule (E). In frames F, G and $\mathrm{H}$, the alpha-3 helix, a docked conformation of the designed compound and their superpositions, are represented respectively. In these frames the IBD surface is colored according to the electrostatic interactions.

for pharmacophore guided scaffold replacement, describes the projection of the interacting amino acids (Thr-124 and Trp-131) onto a small molecule scaffold in such a way that the core has maximal contact with the IBD surface, by translating the Ala-127 into a hydrophobic or aromatic feature (see Fig. 2E). Several core options are plausible, and the compound presented here was chosen since it showed the highest electrostatic field similarity with the mimicked alpha helix. Additionally this compound's docked binding mode was in agreement with the molecules conformation and interactions according to the pharmacophore guided scaffold replacement strategy (Fig. 2F, G and H). Furthermore, in the designed compound Thr-124 was replaced with an isopropyl functionality to increase the hydrophobic interacting surface of the inhibitor as well as the chemical feasibility. The sulfur linker was chosen because its atom's size was found to be optimal to span the distance between the aromatic scaffold and the indole moiety.

To explore the necessity of the functional groups on the molecules and to explore a putative Structure Activity Relationship (SAR), additional derivatives of the de novo designed CAB-inhibitor were generated.

\section{Synthesis of the molecules}

The synthesis of the de novo designed CAB-inhibitors has been accomplished by amide coupling of an appropriately substituted
3-(1H-indol-3-ylthio)benzoic acid with a 2,6-dialkoxypyridin-3amine. These compounds were generated as indicated in the retrosynthetic Scheme 1.

The sulfynilation of the variously substituted indoles 1a-d was accomplished with $\mathrm{FeCl}_{3}$ as catalyst in acetonitrile ${ }^{26}$ under microwave irradiation ${ }^{27,28}$ at a ceiling temperature of $140{ }^{\circ} \mathrm{C}$ and a maximum power of $150 \mathrm{~W}$ for $30 \mathrm{~min}$, yielding the desired compounds with a 90-96\% yield (Scheme 2). Remarkably, under conventional heating at reflux temperature the reaction requires $6 \mathrm{~h}$ to reach completion and the desired compound 3a could only be obtained in a moderate yield of $50 \%$ due to the formation of an unidentified by-product.

According to our previously optimized protocol, ${ }^{29}$ pyridone 4 has been subjected to $O$-alkylation using different alkyl halides in the presence of $\mathrm{Ag}_{2} \mathrm{CO}_{3}$ under microwave irradiation to afford compounds $\mathbf{5 a}, \mathbf{b}$. Treatment of $\mathbf{5 a}, \mathbf{b}$ with $\mathrm{NaOMe}$ in $\mathrm{MeOH}$ at reflux temperature for $1 \mathrm{~h}$ resulted in the formation of the intermediates 7a. Compound $7 \mathbf{c}$ could directly be formed from 2,6-dichloro-3-nitropyridine (6) using an excess of $\mathrm{NaOMe}$ in $\mathrm{MeOH}$ for $2 \mathrm{~h}$ at reflux temperature. Compounds $7 \mathrm{a}-\mathbf{c}$ were subsequently reduced to the corresponding 3-aminopyridines 8ac via a $\mathrm{Pd} / \mathrm{C}$-catalysed hydrogenation at 25 psi pressure at r.t. for 2 h (Scheme 3).

The two key building blocks $\mathbf{3}$ and $\mathbf{8}$ were then coupled using HOAt, EDC. $\mathrm{HCl}$ and $N$-methyl morpholine under microwave 


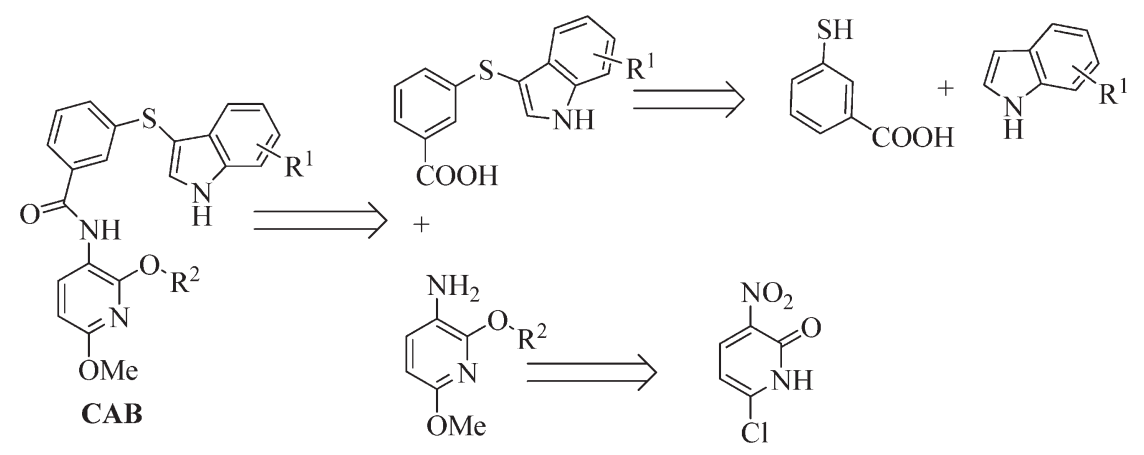

Scheme 1 Retrosynthetic analysis of the designed compounds.

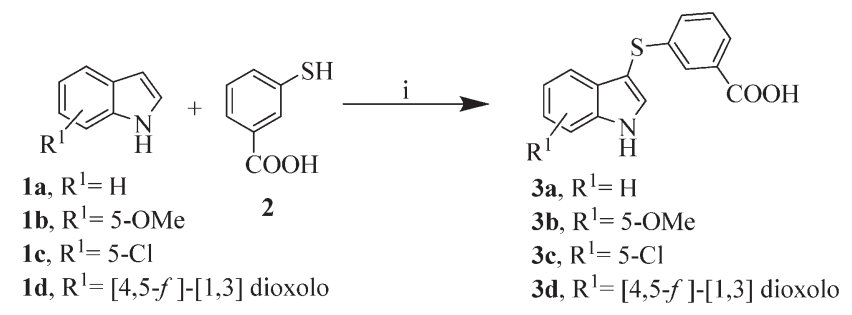

Scheme 2 Synthesis of intermediates 3a-d. Reagents and conditions: i) $\mathrm{FeCl}_{3}(20 \% \mathrm{~mol})$, acetonitrile, $\mathrm{MW}: 140{ }^{\circ} \mathrm{C}, 150 \mathrm{~W}, 30 \mathrm{~min}, 90-96 \%$.

irradiation at a ceiling temperature of $80{ }^{\circ} \mathrm{C}$ and a maximum power of $80 \mathrm{~W}$ for 20 min to give the desired final compounds CAB1-8 with $55-75 \%$ yields (Table 1).

Next we extended the series by using two commercially available anilines following the previous amide coupling procedure. In this way compounds CAB9, 10 were obtained (Fig. 3). The synthesis of the 2-isopropoxy analogue of CAB9 was attempted, however we were unable to isolate the desired compound. To verify the importance of the indole moiety we also synthesized compounds $\mathbf{C A B 1 1 , 1 2}$ in which the indole ring has been omitted. Condensation of the intermediates 8a,c with the commercially available 3-(methylthio)-benzoic acid or benzoic acid respectively, resulted in the desired compounds (Fig. 3).

Since the indole binding area lays on a downwardly bent surface with respect to the other part of the inhibitor binding site, a rigidification of the linker of the indole moiety was attempted, while taking the correct $3 \mathrm{D}$ organization of the chemical functionalities into account. As such, the thioether linkage in CAB1, has been replaced by a carbonyl, leading to the synthesis of compound CAB13 (Scheme 4). Friedel-Crafts acylation of indole with the acid chloride of the mono-methyl isophtalate (9) was carried out with diethylalluminiumchloride ${ }^{30}$ resulting in the formation of compound 10. After saponification with $\mathrm{NaOH}(2 \mathrm{M})$ the benzoic acid derivative 11 was coupled with 8a applying the previously described conditions, resulting in the formation of the desired compound CAB13.

\section{Biological evaluation}

All compounds CAB1-13 were evaluated for their ability to inhibit the LEDGF/p75-IN interaction in a test tube proteinprotein interaction assay.

The synthesized CAB-compounds were first tested in the AlphaScreen assay to evaluate inhibition of the interaction between LEDGF/p75 and HIV-1 IN. The originally designed CAB1 showed a 50\% inhibition of the interaction (Table 2). To improve the potency and to investigate the SAR we modified both the indole and the pyridine core. We first decided to introduce different substituents at the C-5 position of the indole such as $\mathrm{Cl}$, OMe and the bulkier [4,5-f]-[1,3] dioxolo. The electron-donating methoxy group (Table 2, CAB4) was equally tolerated as well as the [4,5-f]-[1,3] dioxolo (Table 2, CAB8) whereas the introduction of the electronegative chlorine caused a complete loss of activity (Table 2, CAB6). The changes in the substitution of the indole core were combined with the replacement of the isopropoxy- with a methoxy-group on the pyridine core; no relevant biological difference was observed

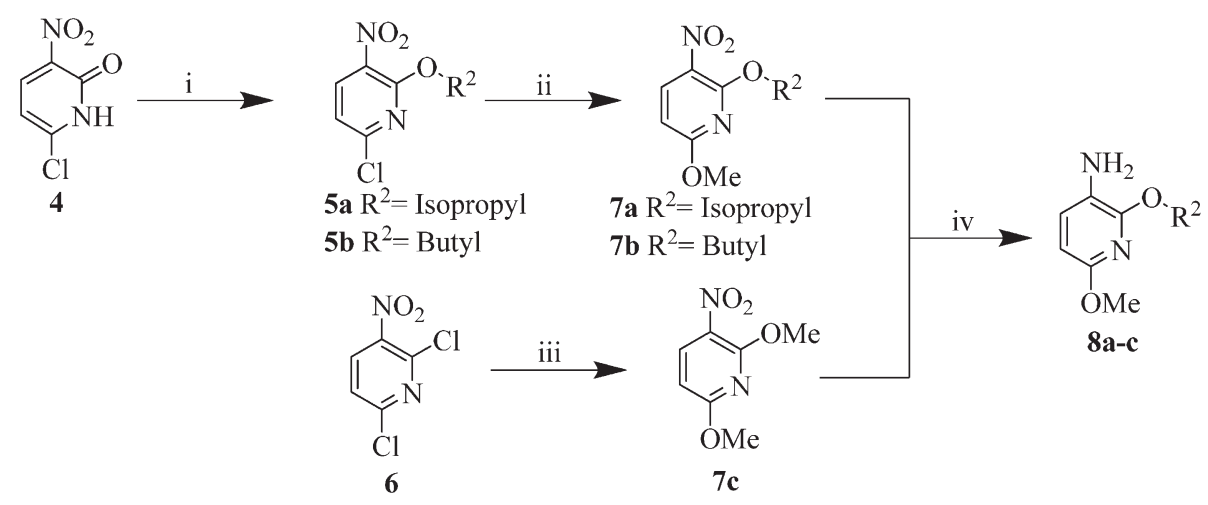

Scheme 3 Synthesis of intermediates $\mathbf{8 a - c .}$ 
Table 1 Synthesis and yields of final compounds CAB1-8 $\mathbf{8}^{a}$

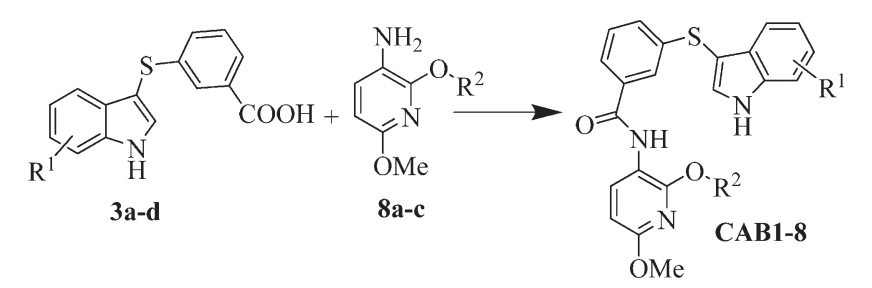

\begin{tabular}{llll}
\hline Compound & $\mathrm{R}^{1}$ & $\mathrm{R}^{2}$ & Yield $^{b}(\%)$ \\
\hline CAB1 & $\mathrm{H}$ & Isopropyl & 75 \\
CAB2 & $\mathrm{H}$ & Butyl & 63 \\
CAB3 & $\mathrm{H}$ & Methyl & 65 \\
CAB4 & $5-\mathrm{OMe}$ & Isopropyl & 70 \\
CAB5 & $5-\mathrm{OMe}$ & Methyl & 50 \\
CAB6 & $5-\mathrm{Cl}$ & Isopropyl & 65 \\
CAB7 & $5-\mathrm{Cl}$ & Methyl & 60 \\
CAB8 & {$[4,5-f]-[1,3]$ dioxolo } & Methyl & 55
\end{tabular}

${ }^{a}$ Reactions were performed with benzoic acids $3(0.25 \mathrm{mmol})$ in DCM ( $2 \mathrm{~mL}$ ) using 3-aminopyridines 8 (1.3 equiv), EDC.HCl (1.3 equiv), HOAt (1.3 equiv) and $N$-methyl morpholine (1.3 equiv) under microwave irradiation at a ceiling temperature of $80{ }^{\circ} \mathrm{C}$ and a maximum power of $80 \mathrm{~W}$ for $20 \mathrm{~min}$. EDC. $\mathrm{HCl}=1$-Ethyl-3-(3dimethyllaminopropyl)carbodiimide hydrochloride; HOAt = 1-hydroxy7-azabenzotriazole. ${ }^{b}$ isolated yields are given.

(Table 2, CAB3,5,7). The introduction of the bulkier butoxy group on the pyridine core, to enhance the hydrophobic interactions, did not result in an important change of the activity (Table 2, CAB2). We speculate that the electronic nature of the pyridine ring rather than the hydrophobic interaction appears to be crucial for the biological activity. In fact the replacement of the pyridine system with a benzene ring, combined with the introduction of the less bulky methoxy side chain group, showed a slight activity improvement (Table 2, CAB9). The absence of a substituent at the C-2 position of the benzene caused an activity decrease (Table 2, CAB10).

Next we examined the importance of the indole. Therefore two derivatives were synthesized in which the indole core was omitted or replaced by a methyl group (Table 2, CAB12 and 11, respectively). However, both modifications appeared to be detrimental for the inhibition underlining the relevance of the indole moiety for the biological activity. To give more rigidity to the indole side chain we replaced the thioether linker with a carbonyl moiety. Unfortunately the analogue CAB13 did not inhibit the IN-LEDGF/p75 interaction (Table 2, CAB13).

For the compounds showing $50 \%$ inhibition or better in the IN-LEDGF/p75 protein-protein interaction assay, the $E C_{50}$ values for inhibition of $\mathrm{HIV}-1$ replication in cell culture were measured, as well as their potency to inhibit the interaction of LEDGF/p75 with its cellular interactor JPO2 (Table 3). The most active compound of our series, CAB9 (Table 3), bears an indole linked to the central core of the molecule via a thioether bond; the substituted pyridine ring has been replaced by a 2,4dimethoxyaniline, thus simplifying the chemistry.

Furthermore, the AlphaScreen based LEDGF/p75-JPO2 inhibition assay indicated that these inhibitors not only inhibit the interaction between LEDGF/p75 and the viral IN, but also its natural interacting protein JPO2. This expected result originates from the fact that targeting the LEDGF/p75 protein with a small molecule on the IBD surface will also disrupt the interaction of its cellular binding partners, since Maertens, et $a l .{ }^{13}$ have indicated that JPO2 binds to LEDGF/p75 on the same region as IN does. As such this proves that the CAB derivatives truly inhibit the LEDGF/p75-IN interaction by binding the IBD and not by binding on the IN protein such as the previously identified LEDGINS. ${ }^{20}$ In fact the IN protein and the JPO2 are sequentially and structurally not related to each other, excluding that the inhibitors reported here act by binding to IN as well as JPO2. The MTT drug susceptibility assay revealed that all evaluated compounds clearly enter the cell, which is demonstrated by the observed cytotoxicity. This, together with the in vitro influence of our compounds on the natural binding partner of LEDGF/p75, indicates that the compounds truly inhibit the cellular cofactor LEDGF/p75 and not the HIV-IN, as previously published inhibitors do.

Although not very high, the cytotoxicity expressed by the CAB-compounds is sufficient to reveal that this series of compounds is inhibiting the cellular role of LEDGF/p75.

For instance it is known that like HIV-1 IN, JPO2 also interacts with the IBD of LEDGF/p75. ${ }^{22}$ The amino acids in the IBD that are critical for IN interaction were proven not crucial for the interaction with JPO2, underlining the differential structural constraints for both interactions. Consequently, more potent compounds could be designed taking into consideration these differences between the specific LEDGF/p75 binding domains targeting only the regions involved into the binding with IN.

\section{Conclusion}

The design and synthesis of novel SMPPIIs inhibiting the LEDGF/p75-IN interaction responsible for the integration of the viral genome into the host DNA is presented. The
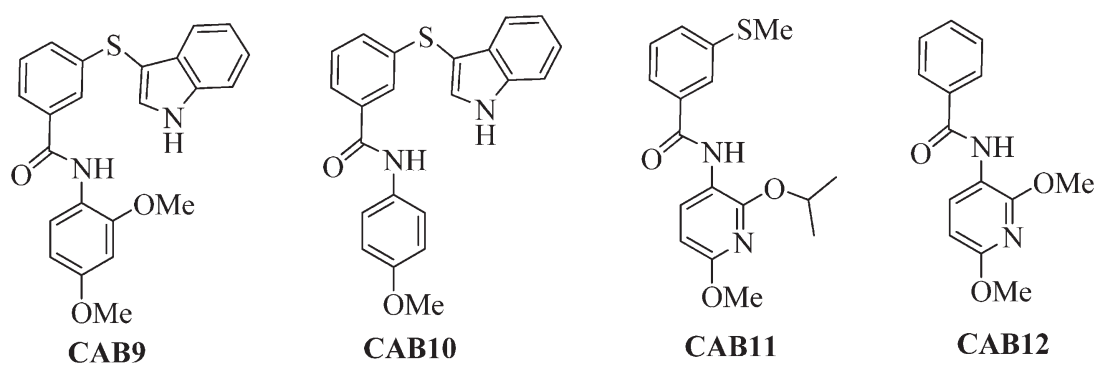

Fig. 3 Structures of compounds CAB9-12. Reagents and conditions: i) $\mathrm{Ag}_{2} \mathrm{CO}_{3}$ (2 equiv), $\mathrm{R}^{2} \mathrm{I}$ (1.2 equiv), hexane, $\mathrm{MW}$ : $150{ }^{\circ} \mathrm{C}, 200 \mathrm{~W}, 10 \mathrm{~min}$, 89-93\%; ii) $\mathrm{NaOMe}$ (1.05 equiv), $\mathrm{MeOH}$, reflux, 2 h, 80-85\%; iii) $\mathrm{NaOMe} \mathrm{(2.5} \mathrm{equiv),} \mathrm{MeOH}$, reflux, 2 h, 90\%; iv) $\mathrm{H}_{2}$, Pd/C, EtOH, 25 psi, r.t., 2 h, $75-82 \%$. 


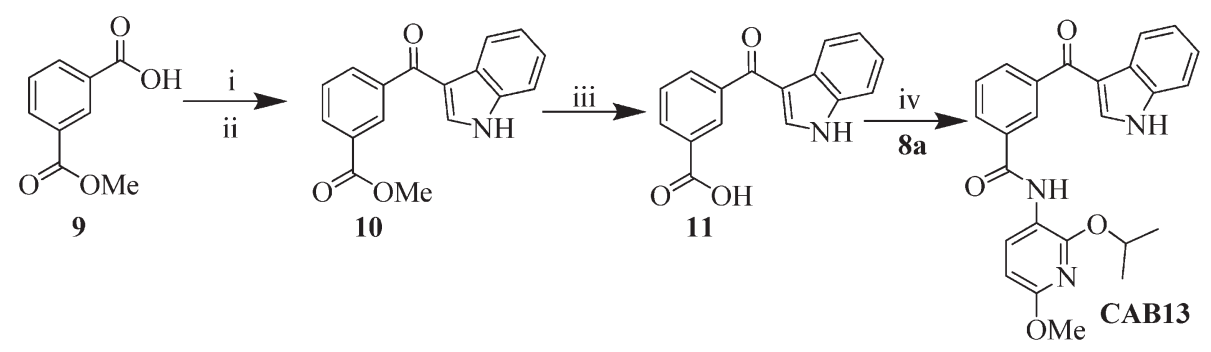

Scheme 4 Synthesis of 3-(1H-indole-3-carbonyl)- $N$-(2-isopropoxy-6-methoxypyridin-3-yl)benzamide (CAB13). Reagents and conditions: i) SOCl ${ }_{2}$, reflux, $1 \mathrm{~h}, 80 \%$; ii) indole, $\mathrm{Et}_{2} \mathrm{AlCl}(0.38 \mathrm{~mL}, 1.8 \mathrm{M}, 0.7 \mathrm{mmol})$, toluene, $0{ }^{\circ} \mathrm{C}, 2 \mathrm{~h}, 50 \%$; iii) $\mathrm{NaOH}(2 \mathrm{M})$, reflux, $4 \mathrm{~h}, 85 \%$; iv) $\mathrm{HOAt}(1.3 \mathrm{equiv})$, $\mathrm{EDC} . \mathrm{HCl}$ (1.3 equiv), 4-methyl morpholine (1.3 equiv), DCM, MW: $80^{\circ} \mathrm{C}, 80 \mathrm{~W}, 20 \mathrm{~min}, 51 \%$.

Table 2 Inhibitory activity of CAB1-13

\begin{tabular}{ll}
\hline Compound & \% Inhibition \\
\hline CAB1 & \\
CAB2 & 50 \\
CAB3 & 33 \\
CAB4 & 40 \\
CAB5 & 55 \\
CAB6 & 33 \\
CAB7 & Not Active \\
CAB8 & Not Active \\
CAB9 & 52 \\
CAB10 & 55 \\
CAB11 & 30 \\
CAB12 & Not Active \\
CAB13 & Not Active \\
${ }^{a}$ Measured at $100 \mu \mathrm{M}$ in triplicate. & Not Active \\
\hline
\end{tabular}

CAB-compounds were rationally designed in agreement with the pharmacophore scaffold replacement model (Fig. 2D). In this model the amino acid residues of IN involved in the interaction with LEDGF/p75, as demonstrated by the crystal structure of the complex, were projected onto a small scaffold to optimize the contacting surface of the IBD of LEDGF/p75. Out of thirteen synthesized analogues, compound CAB9 showed the strongest inhibition of the targeted protein-protein interaction. Experimental evidence is provided that these compounds are in fact LEDGF/p75 binding molecules disrupting the LEDGF/p75 HIV-1 integrase interaction. In this study we wanted to indicate the possibility to rationally design inhibitors that selectively target the LEDGF/p75 partner of the protein-protein interaction, rather than the previously reported structures where the integrase partner was targeted. Currently the potency of the described compounds is not sufficient to inhibit HIV-replication in cell culture, but further efforts, in order to increase the specificity of such compounds towards the critical region of IBD binding to IN and not to other cellular co-factors, are undertaken. We hope, in this way, to improve the activity of this novel and promising series of SMPPII.

\section{Experimental section}

\section{Molecular modelling}

Analysis of the protein-protein interaction between the CCD of HIV-1 Integrase with the IBD of LEDGF/p75 was done using the Brugel software package. ${ }^{31}$ The crystal structures of the interacting domains of interest (CCD and IBD) were retrieved from the PDB repository (PDB entry 2B4J). ${ }^{32}$ The non-bonded interactions between the two partners were determined per amino acid using a CHARMM based force field. ${ }^{33}$

All molecular modeling experiments involving small molecules were performed using the Molecular Operating Environment (MOE) (The Chemical Computing Group, Montreal, Canada) and the latest available version of the GOLD docking algorithm.

All alpha helix mimetic molecules (Fig. 2, panel B and C) were modeled by sketching and their optimal conformation was analyzed by conformational analysis. The docking of the ligand compounds was performed using the pharmacophore constrained docking method as implemented in MOE. Subsequently the Trp131 residue was described with 3 pharmacophore features and the Thr-124 and the Ala-127 each with one hydrophobic feature.

The de novo design of a non alpha helix-mimetic molecule was done using the pharmacophore based scaffold replacement method implemented in MOE. The interacting amino acids Thr-124 and Trp-131 were retained as molecular functionality with their linking atom bonds as pharmacophore linking features, while amino acid Ala-127 was described as a "hydrophobic $O R$ aromatic" pharmacophore feature. This pharmacophore query was used to find a scaffold replacement, from the provided scaffold database [MOE2009.10 distribution, containing approximately 750,000 scaffolds] that links the two chemical groups. Possible chemical solutions were analyzed for synthetic

Table $3 I C_{50}$ values of the most potent CAB-derivatives

\begin{tabular}{lllll}
\hline Compound & $I C_{50}{ }^{a}$ value $(\mu \mathrm{M})$ & MTT:MT-4 $E C_{50}{ }^{b}(\mu \mathrm{M})$ & MTT:MT-4 $C C_{50}{ }^{c}(\mu \mathrm{M})$ & JPO2 $\%{ }^{d}$ inhibition \\
\hline CAB1 & 64 & $>48$ & 48 & 42 \\
CAB4 & $>100$ & $>38$ & 38 & 32 \\
CAB8 & $>100$ & $>29$ & 29 & 36 \\
CAB9 & 30 & $>10$ & 10 & 37
\end{tabular}

${ }^{a} 50 \%$ inhibitory concentration as determined by AlphaScreen. ${ }^{b}$ Effective concentration required to reduce HIV-1 induced cytopathic effect by $50 \%$ in MT-4 cells. ${ }^{c}$ Cytotoxic concentration reducing MT-4 cell viability by $50 \%$. ${ }^{d}$ Measured at $100 \mu$ M. All values represent the average of triplicates. 
feasibility as well as retaining the desired conformation during conformational analysis. To fulfil the pharmacophore, the class of CAB-compounds was designed in such a way that the indole moiety is linked with the alkoxy group via a thio-ether bond.

\section{Chemistry}

\section{General remarks}

${ }^{1} \mathrm{H}$ and ${ }^{13} \mathrm{C}$ NMR spectra were recorded on a Bruker Avance 300 $\left(300 \mathrm{MHz},{ }^{1} \mathrm{H} ; 75 \mathrm{MHz}{ }^{13} \mathrm{C}\right)$ and $400\left(400 \mathrm{MHz},{ }^{1} \mathrm{H} ; 100 \mathrm{MHz}\right.$ ${ }^{13} \mathrm{C}$ ) instruments. The chemical shifts are reported in parts per million relative to tetramethylsilane using the residual solvent signal as internal reference. Multiplicities are indicated by $\mathrm{s}$ (singlet), d (doublet), t (triplet), q (quartet), p (pentet), qt (quintet), $\mathrm{m}$ (multiplet) and b (broad). Coupling constants, $J$, are reported in Hertz. Mass spectra were recorded by using a Kratos MS50TC and a Kratos Mach III data system. The ion source temperature was $150-250{ }^{\circ} \mathrm{C}$ as required. High resolution EImass spectra were performed with a resolution of 10000 . The low resolution spectra were obtained with a HP5989A MS instrument. For thin layer chromatography, analytical TLC plates (Alugram SIL G/UV 254 and 70-230 mesh silica gel (E.M.Merck)) were used. Visualization was accomplished with UV (254).

\section{Microwave irradiation experiments}

All microwave irradiation experiments were carried out in a dedicated CEM-Discover monomode microwave apparatus (CEM Corporation P.O. Box 200 Matthews, NC 28106), operating at a frequency of $2.45 \mathrm{GHz}$ with maximum irradiation power of $300 \mathrm{~W}$. Reaction mixtures were efficiently stirred with a magnetic stirrer. The reactions were carried out in a sealed $10 \mathrm{~mL}$ glass vial. The temperature of the reactions was measured by infrared.

\section{General procedure for the thioarylation of the indoles}

A mixture of the indole $\mathbf{1}(0.2 \mathrm{mmol})$, mercaptobenzoic acid (3) $(0.2 \mathrm{mmol})$ and anhydrous $\mathrm{FeCl}_{3}(7 \mathrm{mg}, 20 \mathrm{~mol} \%)$ in acetonitrile $\left(2 \mathrm{~mL}\right.$ ) was irradiated at a ceiling temperature of $140{ }^{\circ} \mathrm{C}$ and a maximum power of $150 \mathrm{~W}$ for $30 \mathrm{~min}$. The progress of the reaction was monitored by TLC and CI-MS. After complete conversion the reaction mixture was cooled by compressed air and brought to r.t.. The $\mathrm{FeCl}_{3}$ was filtered off on Celite, the acetonitrile was evaporated under reduced pressure and the resulted crude product was purified by column chromatography over silica gel (heptane-EtOAc 8:2 containing acetic acid $(0.1 \%))$ yielding the desired products $\mathbf{3 a - 3 d}$ in $90-96 \%$ yield.

3-(1H-Indol-3-ylthio) benzoic acid (3a). It was obtained as a brown oil (92\% yield). ${ }^{1} \mathrm{H}$ NMR (300 MHz, DMSO): 11.76 (bs, $1 \mathrm{H}), 7.82-7.81(\mathrm{~m}, 1 \mathrm{H}), 7.62(\mathrm{~d}, 1 \mathrm{H}, J=7.35 \mathrm{~Hz}), 7.54-7.49(\mathrm{~m}$, 2H), 7.40-7.25 (m, 3H), $7.19(\mathrm{t}, 1 \mathrm{H}, J=7.35 \mathrm{~Hz}) .7 .07(\mathrm{t}, 1 \mathrm{H}, J=$ $7.35 \mathrm{~Hz}) .{ }^{13} \mathrm{C}$ NMR (75 MHz, DMSO): 166.7, 140.0, 136.7, $132.7,131.5,129.3,129.0,128.4,125.7,122.2,118.1,112.4,98.4$. HRMS (EI): calcd. for $\mathrm{C}_{15} \mathrm{H}_{11} \mathrm{NO}_{2} \mathrm{~S}$ : 269.0510; found: 269.0527 .

3-(5-Methoxy-1H-indol-3-ylthio)benzoic acid (3b). It was obtained as a yellow oil $\left(96 \%\right.$ yield). ${ }^{1} \mathrm{H}$ NMR $(300 \mathrm{MHz}$, DMSO): 11.98 (bs, 1H), 7.92-7.91 (m, 1H), 7.65 (d, 1H, $J=$
$7.53 \mathrm{~Hz}), 7.55-7.52(\mathrm{~m}, 2 \mathrm{H}), 7.39-7.34(\mathrm{~m}, 2 \mathrm{H}), 7.29-7.27(\mathrm{~m}$, 1H), 7.22-7.19 (m, 1H). ${ }^{13} \mathrm{C}$ NMR (75 MHz, DMSO): 166.7, 139.5, 135.2, 134.6, 131.5, 129.7, 129.4, 129.2, 125.9, 125.6, 125.0, 122.3, 117.1, 114.1, 98.3. HRMS (EI): calcd. for $\mathrm{C}_{16} \mathrm{H}_{13} \mathrm{NO}_{3} \mathrm{~S}$ : 299.0616, found: 299.0627.

3-(5-Chloro-1H-indol-3-ylthio)benzoic acid (3c). It was obtained as a dark orange oil (90\% yield). ${ }^{1} \mathrm{H}$ NMR $(300 \mathrm{MHz}$, DMSO): 11.63 (bs, 1H), 7.65 (d, 1H, $J=2.64 \mathrm{~Hz}), 7.63$ (d, 1H, $J=$ $7.53 \mathrm{~Hz}), 7.54$ (s, 1H), 7.42-7.25 (m, 3H), 6.84-6.82 (m, 2H), 3.68 (s, 3H). ${ }^{13} \mathrm{C}$ NMR (75 MHz, DMSO): 166.3, 154.3, 140.2, 136.1, 132.1, 131.5, 131.4, 131.1, 129.8, 129.2, 128.4, 127.3, 125.4, 99.4, 97.8, 55.2. HRMS (EI): calcd. for $\mathrm{C}_{15} \mathrm{H}_{10} \mathrm{ClNO}_{2} \mathrm{~S}$ : 303.0121; found: 303.0148 .

3-(5H-[1-3]Dioxolo-[4,5-f]indol-7-ylthio)benzoic (3d). It was obtained as a yellow oil (91\% yield). ${ }^{1} \mathrm{H}$ NMR $(300 \mathrm{MHz}$, DMSO): 11.54 (bs, 1H), 7.64-7.60 (m, 2H), $7.53(\mathrm{~s}, 1 \mathrm{H}), 7.33$ (t, $1 \mathrm{H}, J=7.71 \mathrm{~Hz}), 7.26-7.24(\mathrm{~m}, 1 \mathrm{H}), 7.01(\mathrm{~s}, 1 \mathrm{H}), 6.74(\mathrm{~s}, 1 \mathrm{H})$, 5.95 (s, 2H). ${ }^{13} \mathrm{C}$ NMR (75 MHz, DMSO): 166.8, 144.8, 143.2, 140.0, 131.4, 130.9, 129.3, 129.0, 125.7, 125.5, 122.6, 100.5, 96.5, 98.5, 93.0, 54.9. HRMS (EI): calcd. for $\mathrm{C}_{16} \mathrm{H}_{11} \mathrm{NO}_{4} \mathrm{~S}: 313.0409$; found: 313.0384 .

Compounds $\mathbf{5 a , b}$ were prepared and characterized in accordance with the published procedure. ${ }^{20}$

\section{General procedure for the synthesis of compounds $7 \mathrm{a}, \mathrm{b}$}

A mixture of the 6-chloro-2-alkoxy-3-nitropyridine (5 (0.5 mmol) and anhydrous $\mathrm{NaOMe}(28 \mathrm{mg}, 0.525 \mathrm{mmol})$ was refluxed for $2 \mathrm{~h}$ in dry $\mathrm{MeOH}(6 \mathrm{~mL})$. The progress of the reaction was monitored by TLC and CI-MS. After complete conversion the mixture was cooled to r.t. and the $\mathrm{MeOH}$ was evaporated under reduced pressure. The organic residue was washed with $\mathrm{H}_{2} \mathrm{O}$, extracted with EtOAc and the extract was dried on $\mathrm{Na}_{2} \mathrm{SO}_{4}$. The crude compound was purified by column chromatography over silica gel (heptane-EtOAc $8: 2$ ) giving the desired products $7 \mathbf{a}, \mathbf{b}$ in $72-80 \%$ yield.

2-Isopropoxy-6-methoxy-3-nitropyridine (7a). It was obtained as a dark brown oil (80\% yield). ${ }^{1} \mathrm{H}$ NMR (300 MHz, DMSO): 8.38 (d, 1H, $J=8.67 \mathrm{~Hz}), 6.52(\mathrm{~d}, 1 \mathrm{H}, J=8.85 \mathrm{~Hz}), 5.49-5.41$ (m, 1H), 3.95 (s, 3H), 1.39 (s, 3H), 1.37 (s, 3H). ${ }^{13} \mathrm{C}$ NMR $(75 \mathrm{MHz}$, DMSO): 164.8, 155.9, 139.0, 126.3, 102.4, 71.0, 54.5, 21.6. HRMS (EI): calcd. for $\mathrm{C}_{9} \mathrm{H}_{12} \mathrm{~N}_{2} \mathrm{O}_{4}$ : 212.0797; found: 212.0801 .

2-Butoxy-6-methoxy-3-nitropyridine (7b). It was obtained as a light brown oil (72\% yield). ${ }^{1} \mathrm{H}$ NMR (300 MHz, DMSO): 8.40 $(\mathrm{d}, 1 \mathrm{H}, J=8.85 \mathrm{~Hz}), 6.54(\mathrm{~d}, 1 \mathrm{H}, J=8.67 \mathrm{~Hz}), 4.49(\mathrm{t}, 2 \mathrm{H}, J=$ $6.42 \mathrm{~Hz}), 3.96(\mathrm{~s}, 3 \mathrm{H}), 1.77-1.70(\mathrm{~m}, 2 \mathrm{H}), 1.49-1.42(\mathrm{~m}, 2 \mathrm{H}), 0.94$ (t, 3H, $J=7.35 \mathrm{~Hz}) .{ }^{13} \mathrm{C}$ NMR (75 MHz, DMSO): 153.1, 149.2, 125.1, 124.4, 99.5, 64.6, 52.9, 30.7, 18.7, 13.7. HRMS (EI): calcd. for $\mathrm{C}_{10} \mathrm{H}_{14} \mathrm{~N}_{2} \mathrm{O}_{4}$ : 226.0954; found: 226.0960 .

\section{Procedure for the synthesis of compound 7c}

Compound $7 \mathbf{c}$ was obtained using a slightly modified procedure which consisted of directly refluxing the commercially available 2,6-dichloro-3-nitropyridine (6) (96 $\mathrm{mg}, 5 \mathrm{mmol}$ ) with anhydrous $\mathrm{NaOMe}(80 \mathrm{mg}, 12.5 \mathrm{mmol})$ for $2 \mathrm{~h}$ in dry $\mathrm{MeOH}(6 \mathrm{~mL})$. The 
progress of the reaction was monitored by TLC and CI-MS. After complete conversion the reaction mixture was cooled to r.t., the $\mathrm{MeOH}$ was evaporated under reduced pressure and the organic residue was washed with $\mathrm{H}_{2} \mathrm{O}$ and extracted with EtOAc. The extract was dried on $\mathrm{Na}_{2} \mathrm{SO}_{4}$ and the crude product was purified by column chromatography over silica gel (heptaneEtOAc $8: 2$ ) giving the desired product $7 \mathrm{c}$ in $93 \%$ yield.

2,6-Dimethoxy-3-nitropyridine (7c). It was obtained as a yellow solid (93\% yield), m.p. 89-90 ${ }^{\circ} \mathrm{C} .{ }^{1} \mathrm{H}$ NMR (300 MHz, DMSO): $8.42(\mathrm{~d}, 1 \mathrm{H}, J=8.67 \mathrm{~Hz}), 6.56(\mathrm{~d}, 1 \mathrm{H}, J=8.55 \mathrm{~Hz}), 4.06(\mathrm{~s}, 3 \mathrm{H})$, 3.99 (s, 3H). ${ }^{13} \mathrm{C}$ NMR (75 MHz, DMSO): 164.9, 139.1, 126.2, 102.7, 54.6 (x 2). HRMS (EI): calcd. for $\mathrm{C}_{7} \mathrm{H}_{8} \mathrm{~N}_{2} \mathrm{O}_{4}$ : 184.0484; found: 184.0481 .

\section{General method for the synthesis of compounds $8 \mathrm{a}-\mathrm{c}$}

A mixture of compound $7(0.2 \mathrm{mmol})$ and $5 \% \mathrm{Pd} / \mathrm{C}(5 \mathrm{~mol} \%)$ in $\mathrm{MeOH}(5 \mathrm{~mL})$ was agitated at r.t. under 25 psi hydrogen for $2 \mathrm{~h}$. The catalyst was removed by filtration on Celite and the filtrate was evaporated to dryness to give the pure products $(75-82 \%)$.

2-Isopropoxy-6-methoxypyridin-3-amine (8a). It was obtained as a dark brown oil (82\% yield). ${ }^{1} \mathrm{H}$ NMR (300 $\left.\mathrm{MHz}, \mathrm{CDCl}_{3}\right)$ : $6.93(\mathrm{~d}, 1 \mathrm{H}, J=8.22 \mathrm{~Hz}), 6.13(\mathrm{~d}, 1 \mathrm{H}, J=8.22 \mathrm{~Hz}), 5.33-4-25$ $(\mathrm{m}, 1 \mathrm{H}), 3.81(\mathrm{~s}, 3 \mathrm{H}), 1.37(\mathrm{~s}, 3 \mathrm{H}), 1.35$ (s, 3H). ${ }^{13} \mathrm{C} \mathrm{NMR}(75$ $\mathrm{MHz}_{\mathrm{CDCl}}$ ): 155.4, 150.4, 126.0, 124.0, 99.6, 68.5, 53.7, 22.6. HRMS (EI): calcd. for $\mathrm{C}_{9} \mathrm{H}_{14} \mathrm{~N}_{2} \mathrm{O}_{2}$ 182.1055; found: 182.1057 .

2-Butoxy-6-methoxypyridin-3-amine (8b). It was obtained as a brown oil (75\% yield). ${ }^{1} \mathrm{H}$ NMR (300 MHz, DMSO): 6.94 $(\mathrm{d}, 1 \mathrm{H}, J=8.1 \mathrm{~Hz}), 6.13(\mathrm{~d}, 1 \mathrm{H}, J=8.1 \mathrm{~Hz}), 4.25(\mathrm{t}, 2 \mathrm{H}, J=$ $6.39 \mathrm{~Hz}), 3.70$ (s, 3H), 1.74-1.65 (m, 2H), 1.49-1.37 (m, 2H), 0.93 (t, 3H, $J=7.35 \mathrm{~Hz}) .{ }^{13} \mathrm{C}$ NMR (75 MHz, DMSO): 153.1, 149.2, 125.1, 124.4, 99.5, 64.6, 52.9, 30.7, 18.7, 13.7. HRMS (EI): calcd. for $\mathrm{C}_{10} \mathrm{H}_{16} \mathrm{~N}_{2} \mathrm{O}_{2}$ 196.1212; found: 196.1218.

2,6-Dimethoxypyridin-3-amine (8c). It was obtained as a dark brown oil (80\% yield). ${ }^{1} \mathrm{H}$ NMR $\left(300 \mathrm{MHz}, \mathrm{CDCl}_{3}\right): 6.96(\mathrm{~d}, 1 \mathrm{H}$, $J=7.89 \mathrm{~Hz}), 6.16(\mathrm{~d}, 1 \mathrm{H}, J=7.89 \mathrm{~Hz}), 3.97(\mathrm{~s}, 3 \mathrm{H}), 3.84(\mathrm{~s}, 3 \mathrm{H})$. ${ }^{13} \mathrm{C}$ NMR (75 MHz, $\mathrm{CDCl}_{3}$ ): 153.1, 149.4, 125.1, 124.4, 99.5, 53.0, 52.6. HRMS (EI): calcd. for $\mathrm{C}_{7} \mathrm{H}_{10} \mathrm{~N}_{2} \mathrm{O}_{2}$ 154.0742; found: 154.0724 .

\section{General procedure for the synthesis of compound $\mathbf{1 0}$}

To perform the Friedel-Crafts acylation, the commercially available mono-methyl isophtalate (9) was converted to the corresponding acid chloride in accordance with the published procedure. $^{30}$ To a DCM (2 mL) solution of indole (1a) $(54 \mathrm{mg}$, $0.46 \mathrm{mmol})$ was added diethylalluminum chloride $(0.38 \mathrm{~mL}$, $0.7 \mathrm{mmol}, 1.8 \mathrm{M}$ in toluene) at $0{ }^{\circ} \mathrm{C}$. The mixture was stirred at $0{ }^{\circ} \mathrm{C}$ for $30 \mathrm{~min}$ and then the acid chloride derivative of compound 9 (81 $\mathrm{mg}, 0.69 \mathrm{mmol})$ in DCM $(2 \mathrm{~mL})$ was added drop wise. The resulting solution was stirred at $0{ }^{\circ} \mathrm{C}$ for $2 \mathrm{~h}$ and then brought to r.t.. A pH 7 phosphate buffer was added to quench the reaction and the mixture was extracted with EtOAc. The combined organic layers were concentrated under vacuum and the residue was purified by column chromatography over silica gel (heptane-EtOAc $9: 1$ ) yielding the desired compound in $63 \%$.
Methyl 3-(1H-indol-3-carbonyl)benzoate (10). It was obtained as a white solid (63\% yield), m. p. $209-210{ }^{\circ} \mathrm{C},{ }^{1} \mathrm{H}$ NMR (300 MHz, DMSO): 12.15 (bs, 1H), 8.29 (s, 1H), 8.24 (d, 1H, $J=$ $8.49 \mathrm{~Hz}), 8.17(\mathrm{~d}, 1 \mathrm{H}, J=7.71 \mathrm{~Hz}), 8.06(\mathrm{~d}, 1 \mathrm{H}, J=7.53 \mathrm{~Hz})$, $7.98(\mathrm{~s}, 1 \mathrm{H}), 7.71(\mathrm{t}, 1 \mathrm{H}, J=7.71 \mathrm{~Hz}), 7.53(\mathrm{~d}, 1 \mathrm{H}, J=6.78 \mathrm{~Hz})$, 7.31-7.25 (m, 2H), 3.90 (s, 3H). ${ }^{13} \mathrm{C}$ NMR (75 MHz, DMSO): 188.9, 165.8, 140.7, 136.7, 136.1, 132.9, 131.4, 129.7, 129.1, 128.7, 126.0, 123.3, 122.1, 121.3, 114.7, 112.3, 52.3. HRMS (EI): calcd. for $\mathrm{C}_{17} \mathrm{H}_{13} \mathrm{NO}_{3}$ 279.0895; found: 279.0907 .

\section{General procedure for the synthesis of compound 11}

A suspension of the ester $10(50 \mathrm{mg}, 0.178 \mathrm{mmol})$ in $\mathrm{NaOH}$ ( $5 \mathrm{~mL}, 2 \mathrm{M}$ ) was refluxed until no more starting material was observed (TLC and CI-MS monitoring). The mixture was neutralized with $\mathrm{HCl}(1 \mathrm{M})$ and extracted with EtOAc. The organic layers were combined and concentrated under vacuum. The crude product 11 (40 mg) was directly used without further purification.

3-(1H-Indol-3-carbonyl)benzoic acid (11). It was obtained as a white solid (85\% yield). ${ }^{1} \mathrm{H}$ NMR (300 MHz, DMSO): 12.12 (bs, $1 \mathrm{H}), 8.28-8.23(\mathrm{~m}, 2 \mathrm{H}), 8.17-8.14(\mathrm{~m}, 1 \mathrm{H}), 8.04-7.97(\mathrm{~m}, 2 \mathrm{H})$, 7.68-7.64 (m, 1H), 7.55-7.52 (m, 1H), 7.27-7.25 (m, 2H). HRMS (EI): calcd. for $\mathrm{C}_{16} \mathrm{H}_{11} \mathrm{NO}_{3} 265.0739$; found 265.0747 .

General procedure for the formation of the amides CAB1-13. A mixture of thioether $3(0.25 \mathrm{mmol}), 3$-aminopyridine $\mathbf{8}$ (0.325 mmol), EDC.HCl (0.325 mmol), HOAt $(0.325 \mathrm{mmol})$ and $N$-methyl-morpholine $(0.325 \mathrm{mmol})$ in DCM $(2 \mathrm{~mL})$ was irradiated at a ceiling temperature of $80{ }^{\circ} \mathrm{C}$ and a maximum power of $80 \mathrm{~W}$ for $20 \mathrm{~min}$. The progress of the reaction was monitored by TLC and CI-MS. After completion of the reaction the mixture was cooled by compressed air and brought to r.t.. The mixture was washed with $\mathrm{KHSO}_{4}, \mathrm{NaHCO}_{3}$ and $\mathrm{H}_{2} \mathrm{O}$. The combined extracts were dried on $\mathrm{Na}_{2} \mathrm{SO}_{4}$ and concentrated under vacuum. The resulting crude product was purified by column chromatography over silica gel (heptane-EtOAc $8: 2$ ) giving the desired products CAB1-13 in $50-80 \%$ yields.

3-(1 H-Indol-3-ylthio)- $\boldsymbol{N}$-(2-isopopoxy-6-methoxypyridin-3yl)benzamide (CAB1). It was obtained as a brown oil (75\% yield). ${ }^{1} \mathrm{H}$ NMR (400 MHz, DMSO): 11.75 (bs, 1H), 9.36 (bs, 1H), 7.81, $(\mathrm{s}, 1 \mathrm{H}), 7.76(\mathrm{~d}, 1 \mathrm{H}, J=8.04 \mathrm{~Hz}), 7.61(\mathrm{~s}, 2 \mathrm{H}), 7.50(\mathrm{~d}, 1 \mathrm{H}, J=$ $8.28 \mathrm{~Hz}), 7.40(\mathrm{~d}, 1 \mathrm{H}, J=8.04 \mathrm{~Hz}), 7.34(\mathrm{t}, 1 \mathrm{H}, J=8.04 \mathrm{~Hz})$, $7.21-7.15(\mathrm{~m}, 2 \mathrm{H}), 7.07$ (t, $1 \mathrm{H}, J=7.08 \mathrm{~Hz}), 6.34$ (d, 1H, $J=8.32$ $\mathrm{Hz}), 5.20-5.17(\mathrm{~m}, 1 \mathrm{H}) 3.82(\mathrm{~s}, 3 \mathrm{H}), 1.28(\mathrm{~d}, 6 \mathrm{H}, J=6.28) .{ }^{13} \mathrm{C}$ NMR (100 MHz, DMSO):165.4, 159.8, 155.4, 140,4 138.2, 137.2, 135.5, 133.1, 129.4, 128.9, 128.6, 124.9, 124.3, 122.6, 120.7, 118.6, 114.1, 112.9, 100.3, 99.1, 69.1, 53.7, 22.3. HRMS (EI): calcd. for $\mathrm{C}_{24} \mathrm{H}_{23} \mathrm{~N}_{3} \mathrm{O}_{3} \mathrm{~S}: 433.1460$, found: 433.1462 .

3-(1 H-Indol-3-ylthio)- $\mathrm{N}$-(2-butoxy-6-methoxypyridin-3-yl)benzamide (CAB2). It was obtained as a brown oil (54\% yield). ${ }^{1} \mathrm{H}$ NMR (300 MHz, DMSO): 11.75 (bs, 1H), 9.49 (bs, 1H), 7.81 (s, $1 \mathrm{H}), 7.73(\mathrm{~d}, 1 \mathrm{H}, J=8.28 \mathrm{~Hz}), 7.64(\mathrm{~m}, 2 \mathrm{H}), 7.50(\mathrm{~d}, 1 \mathrm{H}, J=$ $7.92 \mathrm{~Hz}), 7.40(\mathrm{~d}, 1 \mathrm{H}, J=7.71 \mathrm{~Hz}), 7.33(\mathrm{~m}, 1 \mathrm{H}), 7.19-7.07(\mathrm{~m}$, $4 \mathrm{H}), 6.36(\mathrm{~d}, 1 \mathrm{H}, J=8.28 \mathrm{~Hz}), 4.29(\mathrm{t}, 2 \mathrm{H}, J=6.39 \mathrm{~Hz}), 3.83(\mathrm{~s}$, $3 \mathrm{H}), 1.68-1.63(\mathrm{~m}, 2 \mathrm{H}), 1.41-1.37(\mathrm{~m}, 2 \mathrm{H}), 0.89(\mathrm{~m}, 3 \mathrm{H}) .{ }^{13} \mathrm{C}$ 
NMR (75 MHz, DMSO): 164.9, 159.5, 155.6, 139.9, 138.1, 136.7, $134.9,132.6,128.9,128.4,128.1,124.4,123.8,122.1,120.1,118.1$, 113.4, 112.3, 100.0, 98.6, 65.3, 53.3, 30.5, 18.6, 13.6. HRMS (EI): calcd. for $\mathrm{C}_{24} \mathrm{H}_{22} \mathrm{ClN}_{3} \mathrm{O}_{3} \mathrm{~S}$ : 447.1617; found: 447.1623 .

3-(1H-Indol-3-ylthio)- $N$-(2,6-dimethoxypyridin-3-yl)benzamide (CAB3). It was obtained as a brown oil (65\% yield). ${ }^{1} \mathrm{H}$ NMR (300 MHz, DMSO):11.76 (bs, 1H), 9.58 (bs, 1H), 7.82 (d, 1H, $J=$ $2.07 \mathrm{~Hz}), 7.74(\mathrm{~d}, 1 \mathrm{H}, J=8.1 \mathrm{~Hz}), 7.67-7.65(\mathrm{~m}, 2 \mathrm{H}), 7.51(\mathrm{~d}, 1 \mathrm{H}$, $J=7.92 \mathrm{~Hz}), 7.41(\mathrm{~d}, 1 \mathrm{H}, J=7.74 \mathrm{~Hz}), 7,32(\mathrm{t}, 1 \mathrm{H}, J=7.74 \mathrm{~Hz})$, $7.30-7.16(\mathrm{~m}, 2 \mathrm{H}), 7.97(\mathrm{t}, 1 \mathrm{H}, J=7.53 \mathrm{~Hz}), 6.38(\mathrm{~d}, 1 \mathrm{H}, J=$ $8.28 \mathrm{~Hz}), 3.87$ (s, 3H), 3.85, (s, 3H). ${ }^{13} \mathrm{C}$ NMR (75 MHz, DMSO): 164.8, 159.6, 155.7, 139.8, 138.2, 136.7, 134.6, 132.6, 128.8, 128.4, $124.5,123.9,122.2,120.2,118.1,113.3,112.4,105.8,100.1,98.6$, 153.3, 53.2. HRMS (EI): calcd. for $\mathrm{C}_{22} \mathrm{H}_{19} \mathrm{~N}_{3} \mathrm{O}_{3} \mathrm{~S}$ : 405.1147; found: 405.1136 .

$N$-(2-Isopropoxy-6-methoxypyridin-3-yl)-3-(5-methoxy$\mathbf{1 H}$-indol-3-ylthio)benzamide (CAB4). It was obtained as a brown oil (70\% yield). ${ }^{1} \mathrm{H}$ NMR (300 MHz, DMSO):11.63 (bs, 1H), 9.38 (bs, 1H), 7.77-7.74 (m, 2H), 7.64-7.61 (m, 2H), $7.40(\mathrm{~d}, 1 \mathrm{H}$, $J=9.42 \mathrm{~Hz}), 7.34(\mathrm{t}, 1 \mathrm{H}, J=8.1 \mathrm{~Hz}), 7.15(\mathrm{~d}, 1 \mathrm{H}, J=7.92 \mathrm{~Hz})$, 6-85-6.82 (m, 2H), $6.34(\mathrm{~d}, 1 \mathrm{H}, J=8.31 \mathrm{~Hz}), 5.23-5.14(\mathrm{~m}, 1 \mathrm{H})$, $3.82(\mathrm{~s}, 3 \mathrm{H}), 3.69$ (s, 3H), 1.28 (s, 3H), 1.26 (s, 3H) ${ }^{13} \mathrm{C} \mathrm{NMR}$ (75 MHz, DMSO): 164.9, 159.3, 154.9, 154.3, 140.0, 137.8, 135.0, 133.1, 131.6, 129.3, 128.9, 124.2, 123.7, 113.6, 113.2, 112.3, 99.8, 99.5, 97.9, 68.6, 55.2, 53.2, 30.6, 21.8. HRMS (EI): calcd. for $\mathrm{C}_{25} \mathrm{H}_{25} \mathrm{~N}_{3} \mathrm{O}_{4} \mathrm{~S}$ : 463.1566; found: 463.1548 .

$\boldsymbol{N}$-(2,6-Dimethoxypyridin-3-yl)-3-(5-methoxy-1 $\boldsymbol{H}$-indol-3ylthio)benzamide (CAB5). It was obtained as a brown oil $(50 \%$ yield). ${ }^{1} \mathrm{H}$ NMR (300 MHz, DMSO): 11.62 (bs, 1H), 9.57 (bs, $1 \mathrm{H}), 7.75-7.73(\mathrm{~m}, 2 \mathrm{H}), 7.66(\mathrm{~m}, 2 \mathrm{H}), 7.40(\mathrm{~d}, 1 \mathrm{H}, J=9.42 \mathrm{~Hz})$, $7.33(\mathrm{t}, 1 \mathrm{H}, J=7.89 \mathrm{~Hz}), 7.13(\mathrm{~d}, 1 \mathrm{H}, J=8.1 \mathrm{~Hz}), 6.84-6.82(\mathrm{~m}$, $2 \mathrm{H}), 6.38(\mathrm{~d}, 1 \mathrm{H}, J=8.28 \mathrm{~Hz}), 3.87(\mathrm{~s}, 3 \mathrm{H}), 3.85(\mathrm{~s}, 3 \mathrm{H}), 3.68(\mathrm{~s}$, 3H). ${ }^{13} \mathrm{C}$ NMR (75 MHz, DMSO): 165.3, 160.1, 154.8, 156.2, $140.5,138.6,135.2,133.6,132.1,129.8,129.3,128.5,124.9,124.3$, $113.9,113.7,112.8,100.6,100.1,98.5,55.7,53.8,53.7$. HRMS (EI): calcd. for $\mathrm{C}_{23} \mathrm{H}_{21} \mathrm{~N}_{3} \mathrm{O}_{4} \mathrm{~S}$ : 435.1253 ; found: 435.1250 .

3-(5-Chloro-1 $H$-indol-3-ylthio)- $N$-(2-isopropoxy-6-methoxypyridin-3-yl)benzamide (CAB6). It was obtained as a brown oil (65\%yield). ${ }^{1} \mathrm{H}$ NMR (300 MHz, DMSO):11.96 (bs, 1H), 9.39 (bs, $1 \mathrm{H}), 7.41(\mathrm{~d}, 1 \mathrm{H}, J=2.43 \mathrm{~Hz}), 7.75(\mathrm{~d}, 1 \mathrm{H}, J=8.23 \mathrm{~Hz})$, $7.64(\mathrm{~d}, 1 \mathrm{H}, J=7.89 \mathrm{~Hz}), 7.59(\mathrm{~m}, 1 \mathrm{H}), 7.53(\mathrm{~d}, 1 \mathrm{H}, J=8.67 \mathrm{~Hz})$, $7.39-7.35(\mathrm{~m}, 2 \mathrm{H}), 7.22-7.16(\mathrm{~m}, 2 \mathrm{H}), 6.34(\mathrm{~d}, 1 \mathrm{H}, J=8.38 \mathrm{~Hz})$, 5.22-5.14 (m, 1H), $3.81(\mathrm{~s}, 3 \mathrm{H}), 1.28(\mathrm{~s}, 3 \mathrm{H}), 1.26(\mathrm{~s}, 3 \mathrm{H}) .{ }^{13} \mathrm{C}$ NMR (75 MHz, DMSO): 159.9, 139.8, 138.2, 135.7, 135.0, 130.3, 129.5, 128.7, 125.5, 124.9, 124.5, 122.8, 117.6, 114.6, 114.1, 100.3, 99.1, 69.1, 53.7, 22.3. HRMS (EI): calcd. for $\mathrm{C}_{24} \mathrm{H}_{22} \mathrm{ClN}_{3} \mathrm{O}_{3} \mathrm{~S}$ : 467.1070; found: 467.1086 .

3-(5-Chloro-1 $H$-indol-3-ylthio)- $N$-(2,6-dimethoxypyridin-3yl)benzamide (CAB7). It was obtained as a brown oil (62\% yield). ${ }^{1} \mathrm{H}$ NMR (300 MHz, DMSO): 11.97 (bs, 1H), 9.60 (bs, 1H), 7.92 $(\mathrm{d}, 1 \mathrm{H}, J=2.64 \mathrm{~Hz}), 7.74(\mathrm{~d}, 1 \mathrm{H}, J=8.28 \mathrm{~Hz}), 7.69-7.65(\mathrm{~m}$, $2 \mathrm{H}), 7.53(\mathrm{~d}, 1 \mathrm{H}, J=8.67 \mathrm{~Hz}), 7.35(\mathrm{~m}, 2 \mathrm{H}), 7.22-7.14(\mathrm{~m}, 2 \mathrm{H})$, $6.38(\mathrm{~d}, 1 \mathrm{H}, J=8.28 \mathrm{~Hz}), 3.87(\mathrm{~s}, 3 \mathrm{H}), 3.86(\mathrm{~s}, 3 \mathrm{H}) .{ }^{13} \mathrm{C} \mathrm{NMR}$ (75 MHz, DMSO): 164.7, 159.6, 155.8, 139.3, 136.9, 135.2, 134.7,
$134.5,129.7,129.0,128.2,125.0,124.6,124.1,122.3,117.1,114.1$, 113.3, 100.1, 98.6, 53.3, 53.2. HRMS (EI): calcd. for $\mathrm{C}_{22} \mathrm{H}_{18} \mathrm{ClN}_{3} \mathrm{O}_{3} \mathrm{~S}$ : 439.0757 ; found: 439.0764 .

3-(5H-[1,3-Dioxolo[4,5-f]indol-7-ylthio)- $\mathrm{N}$-(2,6-dimethoxypyridin-3-yl)benzamide (CAB8). It was obtained as a yellow oil (55\% yield). ${ }^{1} \mathrm{H}$ NMR (400 MHz, DMSO): 11.53 (bs, 1H), 9.55 (bs, $1 \mathrm{H}), 7.75$ (d, 1H, $J=8.32 \mathrm{~Hz}), 7.67-7.60(\mathrm{~m}, 1 \mathrm{H}), 7.34$ (t, 1H, $J$ $=7.8 \mathrm{~Hz}), 7.15(\mathrm{~d}, 1 \mathrm{H}, J=8.3 \mathrm{~Hz}), 7.02(\mathrm{~s}, 1 \mathrm{H}), 6.76(\mathrm{~s}, 1 \mathrm{H}), 6.39$ $(\mathrm{d}, 1 \mathrm{H}, J=8.32), 5.95(\mathrm{~s}, 2 \mathrm{H}), 3.88(\mathrm{~s}, 3 \mathrm{H}), 3.86(\mathrm{~s}, 3 \mathrm{H}) \cdot{ }^{13} \mathrm{C}$ NMR(100 MHz, DMSO): 165.3, 160.1, 156.2, 145.3, 143.6, $140.3,138.6,135.2,131.9,129.3,125.0,124.4,123.2,113.9,101.0$, 100.6, 99.3, 97.0, 93.5, 65.3, 53.8, 53.7. HRMS (EI): calcd. for $\mathrm{C}_{25} \mathrm{H}_{23} \mathrm{~N}_{3} \mathrm{O}_{5} \mathrm{~S}: 449.1045$; found: 449.1056 .

3-(1H-Indol-3-ylthio)- $\mathrm{N}$-(2,4-dimethoxyphenyl)benzamide (CAB9). It was obtained as a brown oil (73\% yield). ${ }^{1} \mathrm{H}$ NMR (300 MHz, DMSO): 11.74 (bs, 1H), 9.31 (bs, 1H), 7.81 (s, 1H), $7.63(\mathrm{~m}, 2 \mathrm{H}), 7.52-7.49(\mathrm{~m}, 1 \mathrm{H}), 7.45-7.39(\mathrm{~m}, 2 \mathrm{H}), 7.32(\mathrm{~m}, 1 \mathrm{H})$, 7.19-7.16 (m, 2H), $7.08(\mathrm{~m}, 1 \mathrm{H}), 6.62-6.59(\mathrm{~m}, 1 \mathrm{H}), 6.50(\mathrm{~d}, 1 \mathrm{H}$, $J=8.1 \mathrm{~Hz}), 3.76(\mathrm{~s}, 6 \mathrm{H}) .{ }^{13} \mathrm{C} \mathrm{NMR}(75 \mathrm{MHz}, \mathrm{DMSO}): 164.4$, 157.8, 153.2, 139.8, 136.7, 135.1, 132.6, 128.8, 128.4, 128.0, 126.1, $124.3,123.8,122.1,120.1,119.5,118.1,112.3,104.1,98.8,98.6$, 55.6, 55.2. HRMS (EI): calcd. for $\mathrm{C}_{23} \mathrm{H}_{20} \mathrm{~N}_{2} \mathrm{O}_{3} \mathrm{~S}$ : 404.1195; found: 404.1203 .

3-(1H-Indol-3-ylthio)- $\mathrm{N}$-(4-methoxyphenyl)benzamide (CAB10). It was obtained as a brown oil $(60 \%$ yield $) .{ }^{1} \mathrm{H}$ NMR (300 MHz, DMSO):11.75 (bs, 1H), 10.10 (bs, 1H), 7.81(s, 1H), 7.65-7.60 (m, 4H), $7.50(\mathrm{~d}, 1 \mathrm{H}, J=7.92 \mathrm{~Hz}), 7.40(\mathrm{~d}, 1 \mathrm{H}, J=$ $7.92 \mathrm{~Hz}), 7.32(\mathrm{t}, 1 \mathrm{H}, J=7.71 \mathrm{~Hz}), 7,19(\mathrm{t}, 1 \mathrm{H}, J=7.14 \mathrm{~Hz})$, 7.13-7.04 (m, 2H), 6.89 (d, 2H, $J=8.85 \mathrm{~Hz}), 3.73(\mathrm{~s}, 3 \mathrm{H}) .{ }^{13} \mathrm{C}$ NMR (75 MHz, DMSO): 164.5, 155.5, 139.8, 136.7, 135.6, 132.6, 132.0, 128.8, 127.9, 124.4, 123.9, 122.1, 121.9, 120.1, 118.1, 113.6, 112.4, 98.6, 55.1. HRMS (EI): calcd. for $\mathrm{C}_{22} \mathrm{H}_{18} \mathrm{~N}_{2} \mathrm{O}_{2} \mathrm{~S}$ : 374.1089; found: 374.1072 .

N-(2-Isopropoxy-6-methoxypyridin-3-yl)-3-(methylthio)benzamide (CAB11). It was obtained as a purple oil (84\% yield). ${ }^{1} \mathrm{H}$ NMR (300 MHz, DMSO): 9.48 (bs, 1H), 7.81-7.77 (m, 2H), 7.68 $(\mathrm{s}, 1 \mathrm{H}), 7.46(\mathrm{~m}, 2 \mathrm{H}), 6.37(\mathrm{~d}, 1 \mathrm{H}, J=8.28 \mathrm{~Hz}), 5.26-5.17(\mathrm{~m}$, $1 \mathrm{H}), 3.83(\mathrm{~s}, 3 \mathrm{H}), 2.54(\mathrm{~s}, 3 \mathrm{H}), 1.33(\mathrm{~s}, 3 \mathrm{H}), 1.31(\mathrm{~s}, 3 \mathrm{H}),{ }^{13} \mathrm{C}$ NMR (75 MHz, DMSO): 164.9, 159.4, 155.0, 138.7, 138.0, 135.0, 128.9, 128.6, 124.4, 123.9, 113.6, 99.9, 68.6, 53.2, 21.9, 14.4. HRMS (EI): calcd. for $\mathrm{C}_{17} \mathrm{H}_{20} \mathrm{~N}_{2} \mathrm{O}_{3} \mathrm{~S}$ : 332.1195; found: 332.1170 .

$\mathbf{N}$-(2,6-Dimethoxypyridin-3-yl)benzamide (CAB12). It was obtained as a brown oil (80\% yield). ${ }^{1} \mathrm{H}$ NMR $(300 \mathrm{MHz}$, DMSO): 9.59 (bs, 1H), 7.96 (d, 2H, $J=7.14 \mathrm{~Hz}), 7.80$ (d, 1H, $J=$ $8.28 \mathrm{~Hz}), 7.57$ (d, 1H, $J=7.17 \mathrm{~Hz}), 7.53-7.48(\mathrm{~m}, 2 \mathrm{H}), 6.41$ (d, $1 \mathrm{H}, J=8.28 \mathrm{~Hz}), 3.90(\mathrm{~s}, 3 \mathrm{H}), 3.87(\mathrm{~s}, 3 \mathrm{H}) .{ }^{13} \mathrm{C} \mathrm{NMR}(75 \mathrm{MHz}$, DMSO): $165.3,159.6,155.8,138.2,134.0,131.5,128.3,127.5$, 113.6, 113.5, 100.1, 71.7, 53.3, 53.2. calcd. for $\mathrm{C}_{14} \mathrm{H}_{14} \mathrm{~N}_{2} \mathrm{O}_{3}$ : 258.1004; found: 258.1010 .

3-(1H-Indole-3-carbonyl)- $N$-(2-isopropoxy-6-methoxypyridin3-yl)benzamide (CAB13). It was obtained as white solid (51\% yield)., m. p. $162-163{ }^{\circ} \mathrm{C}^{1} \mathrm{H}$ NMR (400 MHz, $\mathrm{CDCl}_{3}$ ): 9.67 (bs, 
$1 \mathrm{H}), 8.57$ (d, 1H, $J=11.28 \mathrm{~Hz}), 8.41-8.38(\mathrm{~m}, 1 \mathrm{H}), 8.28(\mathrm{~s}, 1 \mathrm{H})$, $8.23(\mathrm{~s}, 1 \mathrm{H}), 8.02-7.95(\mathrm{~m}, 2 \mathrm{H}), 7.59(\mathrm{t}, 1 \mathrm{H}, J=10.32 \mathrm{~Hz}), 7.53$ (d, 1H, $J=3.76 \mathrm{~Hz}), 7.42-7.39(\mathrm{~m}, 1 \mathrm{H}), 7.31-7.28(\mathrm{~m}, 2 \mathrm{H}), 6.32$ $(\mathrm{d}, 1 \mathrm{H}, J=11.32 \mathrm{~Hz}), 5.39-5.31(\mathrm{~m}, 1 \mathrm{H}), 3.87$ (s, 3H), 1.37 (d, $6 \mathrm{H}, J=8.28 \mathrm{~Hz}) .{ }^{13} \mathrm{C}$ NMR $\left(100 \mathrm{MHz}, \mathrm{CDCl}_{3}\right): 190.3,164.8$, $158.6,151.5,141.3,136.6,135.0,134.4,131.9,131.6,129.3,127.1$, 126.2, 124.0, 122.8, 122.2, 116.5, 115.0, 111.7, 100.1, 69.6, 53.6, 22.2. HRMS (EI): calcd. for $\mathrm{C}_{25} \mathrm{H}_{23} \mathrm{~N}_{3} \mathrm{O}_{4}$ : 429.1689; found: 429.1693 .

\section{LEDGF/p75-HIV-1 Integrase interaction screening (AlphaScreen technology)}

AlphaScreen (Amplified Luminiscent Proximity Homogeneous Assay) is a bead-based technology used to study biomolecular interactions in a microtiter plate format. Binding of integrase to LEDGF/p75 leads to an energy transfer from the donor to the acceptor bead. This transfer induces the emission of luminescence. Inhibition of the interaction decreases the emission in a concentration dependent manner.

The AlphaScreen assay was performed according to the manufacturer's protocol (Perkin Elmer, Benelux). Reactions were performed in $25 \mu \mathrm{L}$ final volume in 384-well Optiwell ${ }^{\mathrm{TM}}$ microtiter plates (Perkin Elmer). The reaction buffer contained $25 \mathrm{mM}$ Tris- $\mathrm{HCl}$ (pH 7.4), $150 \mathrm{mM} \mathrm{NaCl}, 1 \mathrm{mM} \mathrm{MgCl} 2,0.01 \%$ $(\mathrm{v} / \mathrm{v})$ Tween-20 and $0.1 \%(\mathrm{w} / \mathrm{v})$ bovine serum albumin. His $6^{-}$ tagged integrase (300 $\mathrm{nM}$ final concentration) was incubated with the compounds for $30 \mathrm{~min}$ at $4{ }^{\circ} \mathrm{C}$. The compounds were added in varying concentrations ranging from 0.1 up to $100 \mu \mathrm{M}$. Afterwards $100 \mathrm{nM}$ flag-LEDGF/p75 was added and incubation was prolonged for an additional hour at $4{ }^{\circ} \mathrm{C}$. Subsequently $5 \mu \mathrm{L}$ of Ni-chelate-coated acceptor beads and $5 \mu \mathrm{L}$ anti-flag donor beads were added to a final concentration of $20 \mu \mathrm{g} \mathrm{mL}^{-1}$ of both beads. Proteins and beads were incubated for $1 \mathrm{~h}$ at $30{ }^{\circ} \mathrm{C}$ to allow association. Exposure of the reaction to direct light was omitted as much as possible and the emission of light from the acceptor beads was measured in the EnVision plate reader (Perkin Elmer, Benelux) and analyzed using the EnVision manager software. In order to analyse the inhibition of the JPO2-LEDGF/p75 interaction a modified protocol was used. Streptavidin-coated donor beads were incubated with biotinylated anti-MBP antibody (Vector laboratories, Burlingame, CA) for $1 \mathrm{~h}$ at room temperature. MBP-JPO2 was bound through the biotinylated anti-MBP antibody to the donor beads. Subsequently the assay was performed as described above.

\section{Drug susceptibility assay}

The inhibitory effect of the compounds on the HIV-induced CPE in MT-4 cell culture was determined by the MTT-assay. ${ }^{34}$ This assay is based on the reduction of the yellow colored 3-(4,5dimethylthiazol-2-yl)-2,5-diphenyltetrazolium bromide (MTT) by mitochondrial dehydrogenase of metabolically active cells to a blue formazan derivative, which can be measured spectrophotometrically. The $50 \%$ cell culture infective dose of the HIV strains was determined by titration of the virus stock using MT-4 cells. For the drug susceptibility assays, MT-4 cells were infected with 100 to $30050 \%$ cell culture infective doses of the HIV strain in the presence of five-fold serial dilutions of the antiviral drugs. The concentration of the compound achieving $50 \%$ protection against the CPE of HIV, which is defined as the $50 \%$ effective concentration $\left(I C_{50}\right.$ value), was determined. The concentration of the compound that was toxic for $50 \%$ of the MT- 4 cells, which is defined as the $50 \%$ cytotoxic concentration $\left(C C_{50}\right)$, was determined as well.

\section{Virus strains}

The origin of the HIV-1 strain $\mathrm{III}_{\mathrm{B}}$ has been described previously. $^{35}$

\section{Expression and purification of recombinant proteins}

His $_{6}$-tagged HIV-1 integrase, $3 \times$ flag-tagged LEDGF/p75 and MBP-JPO2 were purified for AlphaScreen applications as described previously. ${ }^{21,36}$

\section{Acknowledgements}

Financial Support was provided by the Research Fund of the Katholieke Universiteit Leuven (IDO 06/006) and the Fund for Scientific Research-Flanders (Belgium) (F.W.O). A. V. wishes to acknowledge the Research Fund of Katholieke Universiteit Leuven for the postdoctoral fellowship. The authors wish to thank Mr. B. Demarsin for the HRMS and Mr. S. G. Modha for his fruitful discussions and help. We would also like acknowledge the technical help of N. J. Vander Veken (AlphaScreen) and B. Van Remoortel (anti-HIV testing). Dr. B. K. Singh wishes to acknowledge the Department of Science and Technology (DST, India) for funding support.

\section{References}

1 WHO, WHO AIDS Update 2008. 2008.

2 J. C. Tilton and R. W. Doms, Antiviral Res., 2010, 85, 91-100.

3 C. S. Adamson and E. O. Freed, Drug Discovery Today, 2008, 13, 424-432.

4 I. Malet, O. Delelis, M. A. Valantin, B. Montes, C. Soulie, M. Wirden, L. Tchertanov, G. Peytavin, J. Reynes, J. F. Mouscadet, C. Katlama, V. Calvez and A. G. Marcelin, Antimicrob. Agents Chemother., 2008, 52, 1351-1358.

5 P. O. Brown, Curr. Top. Microbiol. Immunol., 1990, 157, 19-48.

6 A. Engelman and R. Craigie, J. Virol., 1992, 66, 6361-6369.

7 F. D. Bushman, A. Engelman, I. Palmer, P. Wingfield and R. Craigie, Proc. Natl. Acad. Sci. U. S. A., 1993, 90, 3428-3432.

8 R. A. Lutzke, C. Vink and R. H. Plasterk, Nucleic Acids Res., 1994, 22, 4125-4131.

9 A. P. Eijkelenboom, R. A. Lutzke, R. Boelens, R. H. Plasterk, R. Kaptein and K. Hard, Nat. Struct. Biol., 1995, 2, 807-810.

10 K. Busschots, A. Voet, M. De Maeyer, J. C. Rain, S. Emiliani, R. Benarous, L. Desender, Z. Debyser and F. Christ, J. Mol. Biol., 2007, 365, 1480-1492.

11 P. Cherepanov, G. Maertens, P. Proost, B. Devreese, J. Van Beeumen, Y. Engelborghs, E. De Clercq and Z. Debyser, J. Biol. Chem., 2003, 278, 372-381.

12 M. Llano, D. T. Saenz, A. Meehan, P. Wongthida, M. Peretz, W. H. Walker, W. Teo and E. M. Poeschla, Science, 2006, 314, 461-464.

13 G. Maertens, P. Cherepanov, Z. Debyser, Y. Engelborghs and A. Engelman, J. Biol. Chem., 2004, 279, 33421-33429.

14 P. Cherepanov, E. Devroe, P. A. Silver and A. Engelman, J. Biol. Chem., 2004, 279, 48883-48892.

15 A. Hombrouck, J. De Rijck, J. Hendrix, L. Vandekerckhove, A. Voet, M. De Maeyer, M. Witvrouw, Y. Engelborghs, F. Christ, R. Gijsbers and Z. Debyser, PLoS Pathog., 2007, 3, 418-430.

16 J. De Rijck, L. Vandekerckhove, R. Gijsbers, A. Hombrouck, J. Hendrix, J. Vercammen, Y. Engelborghs, F. Christ and Z. Debyser, J. Virol., 2006, 80, 11498-11509.

17 L. Q. Al-Mawsawi and N. Neamati, ChemMedChem, 2011, 6(2), 228-241. 
18 L. Du, Y. Zhao, J. Chen, L. Yang, Y. Zheng, Y. Tang, X. Shen and H. Jiang, Biochem. Biophys. Res. Commun., 2008, 375, 139-144.

19 L. De Luca, M. L. Barreca, S. Ferro, F. Christ, N. Iraci, R. Gitto, A. M. Monforte, Z. Debyser and A. Chimirri, ChemMedChem, 2009, 4, 1311-1316.

20 F. Christ, A. Voet, A. Marchand, S. Nicolet, B. A. Desimmie, D. Marchand, D. Bardiot, N. J. Van der Veken, B. Van Remoortel, S. V. Strelkov, M. De Maeyer, P. Chaltin and Z. Debyser, Nat. Chem. Biol., 2010, 6, 442-448.

21 K. Bartholomeeusen, J. De Rijck, K. Busschots, L. Desender, R. Gijsbers, S. Emiliani, R. Benarous, Z. Debyser and F. Christ, J. Mol. Biol., 2007, 372, 407-421.

22 K. Bartholomeeusen, F. Christ, J. Hendrix, J. C. Rain, S. Emiliani, R. Benarous, Z. Debyser, R. Gijsbers and J. De Rijck, J. Biol. Chem., 2009, 284, 11467-11477.

23 S. Hughes, V. Jenkins, M. J. Dar, A. Engelman and P. Cherepanov, J. Biol. Chem., 2010, 285, 541-554.

24 A. Yokoyama and M. L. Cleary, Cancer Cell, 2008, 14, 36-46.

25 J. T. Ernst, J. Becerril, H. S. Park, H. Yin and A. D. Hamilton, Angew. Chem., Int. Ed., 2003, 42, 535-539.

26 J. S. Yadav, B. V. S. Reddy, Y. J. Reddy and K. Praneeth, Synthesis, 2009, 1520-1524.
27 A. Loupy and L. Perreuxin Microwave in Organic Synthesis (ed. A. Loupy), Wiley-VCH, Weinheim, 2006, pp. 134-218.

28 E. Van der Eycken and C. O. Kappein Topics in Heterocyclic Chemistry, ed. G. Springer, Berlin, 2006, pp. 267-304.

29 B. K. Singh, C. Cavalluzzo, M. De Maeyer, Z. Debyser, V. S. Parmar and E. Van der Eycken, Synthesis, 2009, 2725-2728.

30 T. Okauchi, M. Itonaga, T. Minami, T. Owa, K. Kitoh and H. Yoshino, Org. Lett., 2000, 2, 1485-1487.

31 P. Delhaise, M. Bardiaux, M. De Maeyer, M. Prevost, D. Vanbelle, J. Donneux, I. Lasters, E. Vancustem, P. Alard and S. Wodak, J. Mol. Graph. Model., 1988, 6, 219.

32 P. Cherepanov, Z. Y. Sun, S. Rahman, G. Maertens, G. Wagner and A. Engelman, Nat. Struct. Mol. Biol., 2005, 12, 526-532.

33 B. R. Brooks, R. E. Bruccoleri, B. D. Olafson, D. J. States, S. Swaminathan and M. Karplus, J. Comput. Chem., 1983, 4, 187-217.

34 R. Pauwels, J. Balzarini, M. Baba, R. Snoeck, D. Schols, P. Herdewijn, J. Desmyter and E. De Clercq, J. Virol. Methods, 1988, 20, 309-321.

35 A. Adachi, H. E. Gendelman, S. Koenig, T. Folks, R. Willey, A. Rabson and M. A. Martin, J. Virol., 1986, 59, 284-291.

36 K. Busschots, J. Vercammen, S. Emiliani, R. Benarous, Y. Engelborghs, F. Christ and Z. Debyser, J. Biol. Chem., 2005, 280, 17841-17847. 